Title Journal

Criticisms and contradictions of ethnomathematics

Educational Studies in Mathematics

Volume 76, Issue 2, pp 209-230

Cover Date

2011-03-01

$\mathrm{DOI}$

10.1007/s10649-010-9289-7

Print ISSN

0013-1954

Online ISSN

1573-0816

Publisher

Springer Netherlands 


\title{
CRITICISMS AND CONTRADICTIONS OF ETHNOMATHEMATICS
}

\author{
Alexandre Pais \\ Aalborg University, Department of Learning and Philosophy \\ Fibigerstræde 10, 9220 Aalborg, Denmark \\ xande@,learning.aau.dk \\ (00351) 917838806
}

\begin{abstract}
This article aims to contribute to the ongoing discussion about the epistemology and philosophy of ethnomathematics, and to debate its educational implications. It begins by identifying in recent literature two categories of criticism to ethnomathematics: epistemological, related with the way ethnomathematics positions itself in terms of mathematical knowledge; and pedagogical, related to the way ethnomathematical ideas are implicated in formal education. After a description of both of these categories, the pedagogical implications of ethnomathematics are considered by means of confronting the criticisms of recent research in the field. Ethnomathematics research conceives its pedagogical implications in different ways, some of them contradictory. Such contradictions are related with the societal role of school, with the idea that we can "transfer" knowledge from one setting to another, and the tendency to reduce ethnomathematics to a ready-to-apply "tool" for the school-learning of mathematics. The author discusses the first two criticisms in the light of recent research concerned with the social and political dimensions of mathematics education. Concerning the latter, a typical case of an ethnomathematical research study looking at bringing local knowledge into school in the name of promoting diversity is analysed. It is the author's contention that ethnomathematical research runs the risk of conveying an idea of culture where the Other is squeezed from its otherness. The article concludes by arguing that a deeper theoretical discussion is needed in the majority of the research currently done in ethnomathematics so that well intentioned actions do not end up having a result opposite to their aims.
\end{abstract}

Keywords: ethnomathematics, philosophy, school mathematics, multiculturalism, criticism.

\section{Introduction}

To associate the prefix 'ethno' to something so well defined, exact and consensual as mathematics may cause surprise. The idea of a science that is human-proof, as mathematics 
has been conceived along modernity, is splintered when we associate it with the prefix 'ethno'. 'Ethno' shifts mathematics from the places where it has been erected and glorified (university and schools), and spreads it to the world of people, in their diverse cultures and everyday activities. An ethnomathematical program sullies mathematics with the human factor; not an abstract human, but a human situated in space and time that implies different knowledge and different practices. Ethnomathematics as a research program is less a complement to mathematics, than a critique of the knowledge that is valorised as being mathematical knowledge.

Despite this all embracing enterprise, ethnomathematics is often confused with an ethnic or indigenous mathematics. In this article, I take the position that ethnomathematics does not restrict its research to the mathematical knowledge of culturally distinct people, or people in their daily activities. The focus could be academic mathematics, through a social, historical, political and economical analysis of how mathematics has become what it is today. With this background, research on ethnomathematics brought to the mathematics education field new and refreshing insights not just about ethnic or local mathematical knowledge, but also in terms of philosophical, historical and political approaches involved in mathematics and its education. Ubiratan D'Ambrosio (2002) defines ethnomathematics as "a research program in the history and philosophy of mathematics, with obvious pedagogic implications" (p. 27) and points out some of the dimensions involved in the ethnomathematical research: historical, cognitive, epistemological, political, and educational. Although I agree with D'Ambrosio that ethnomathematical research could provide us with a deeper understanding of the history and philosophy of mathematics, I contest the idea that the pedagogical implications of ethnomathematics are obvious. In this article I will focus on the epistemological and educational dimensions of ethnomathematics that, in my view, cannot be fully understood without a focus on the social and political dimension of knowledge and education. My main focus will be educational criticism, concerning the way ethnomathematical ideas are applied in formal educational settings.

A significant part of ethnomathematics research has educational aims (Borba, 1990; Gerdes, 1995; Barton, 1996; Powell \& Frankenstein, 1997; Knijnik, Wanderer \& Oliveira, 2006), seeking to bring to the schools or other formal educational environments (like indigenous schools) the knowledge and the mathematical practices of cultural groups of people. This makes ethnomathematics research part of a multicultural approach in education that during the last thirty years has aimed to open schools to the cultural diversity that characterizes our current societies. Together with globalization, the concern with diversity is 
currently considered to be one of the two main educational functions (Izquierdo \& Mínguez, 2003). While globalization refers to the social need to respond to market globalization which imposes a convergent education by training individuals to perform a role in the global society, diversity demands an integration of different cultures in a model of divergent education, able to educate citizens in what has been called equity within diversity. It seems that there is nothing wrong with the valorisation of different cultures, by contemplating them in the educational context. However, I shall argue that a poor theoretical stance on the way we insert (mathematics) diversity into schools, by obliterating the tension existing between globalization and diversity, ends up conveying an idea of culture where the Other is squeezed from its otherness. This is when a multicultural approach becomes racist, when we are willing to accept the Other as long as it is deprived of all the vicissitudes that characterize its otherness-what the Slovenian philosopher Slavoj Žižek (1992, 2009) refers to as the desubstantialized Other.

In the final section of this article I will develop further Slavoj Žižek's critique of multiculturalism, in connection with the exploration of a typical case of an ethnomathematical research study, which looked at bringing local knowledge into school in the name of promoting cultural diversity. Nonetheless, the same critique has been pointed out both within education and mathematics education. Kincheloe and Steinberg (2008), in the article Indigenous Knowledges in Education, make a review of the complexities, dangers and benefits involved in the way indigenous knowledge is handled in education. As the authors acknowledge " $[\mathrm{w}]$ estern scholars dedicated to the best interests of indigenous people often unwittingly participate in the Western hegemonic process" (p. 141). The authors criticize the way researchers and teachers engage in multicultural education, revealing some common problems with the way Western scholars engage in helping indigenous people, such as what the authors calls "vampirism"-western researchers that do not simply want to work with indigenous people but also to transform their identity and become indigenous persons themselves-, or the way western scholars promote a decontextualization of indigenous knowledge-conceptualization of indigenous knowledge in contexts far removed from its production. Paul Dowling (1998) developed a similar critique regarding ethnomathematics. According to him "[t]o varying degrees, all of this work [studies in ethnomathematics] succeeds in celebrating non-European cultural practices only by describing them in European mathematical terms, that is, by depriving them of their social and cultural specificity" (Dowling 1998, p.14). It is in this sense that I understand Žižek's critique of multiculturalism: the Other is accepted, even celebrated, as long as it is the Other of our gaze. 
In order to develop my argument, I shall start by bringing into discussion important criticisms made of ethnomathematics. Indeed, given the radicalism of the ethnomathematical program (at least as it is put by D'Ambrosio (2002)), it is not surprising that its emergence has been the target of strong criticism. Current ethnomathematics studies are numerous and scattered around the world ${ }^{1}$ and it is difficult to gain an international perspective on how ethnomathematical research is being done. Hence, to criticize something with such different practices and discourses can result in an unreal chimera, if we do not take into consideration the different contexts in which research is conducted. A way to overcome these difficulties requires us to criticize ethnomathematics as a well defined research program, and by analysing the work of the most important ethnomathematical researchers. That was the path chosen by Rowlands and Carson $(2002,2004)$ and Horsthemke and Schäfer (2006), in their epistemological and educational critique of ethnomathematics. This critique, I argue, although apparently pedagogical, is an epistemological critique that claims to highlight academic mathematics as one of the biggest achievements of mankind. As concerns the pedagogical critique made by the latter researchers, and also by Skovsmose and Vithal (1997), I shall articulate it with the contradictions raised by ethnomathematical researchers. Even among these researchers there are contradictions in how they understand the pedagogical implications of ethnomathematics.

Three of these four articles were published in Educational Studies in Mathematics, where a discussion about the epistemological status and educational implications of ethnomathematics has been developed. My discussion will consist of the analysis and confrontation of the criticisms raised in these articles with recent research in ethnomathematics that highlights the contradictions involved when we try to implement mathematical ideas in educational settings. The comprehension about the nature of mathematical knowledge, and how this comprehension is fundamental when we engage in educational tasks, together with the aim of equity desired for mathematics education, justifies the importance of exploring how in our current society mathematics education deals with the situated character of knowledge as it is presented from an ethnomathematical perspective. As schools are considered places in which pupils have access to a set of practices and knowledge indispensable for their formation as citizens, the question of what mathematics should pupils learn is not consensual and, as we shall see, could be a source of conflict that makes visible the political dimensions involved in the aims of school mathematics.

1 For updated information on the international research on ethnomathematics I suggest using the website http://www.ethnomath.org/ (Ethnomathematics Digital Library). 


\section{Epistemological criticisms}

In 2002, Rowlands and Carson wrote an article published in this journal, in which they carried out a critical review of ethnomathematics, by comparing the ethnomathematical program to the curriculum of school mathematics. This article was subsequently answered by Adam, Alangui and Barton (2003), which Rowlands and Carson (2004) later responded to in turn. As raised above, this article also draws on arguments by Horsthemke and Schäfer who wrote two articles presented at the International Congress on Ethnomathematics in 2006, where they followed most of the arguments presented by Rowlands and Carson. Those two sources of criticism present themselves as an educational critique on ethnomathematics but, in the way I analysed the texts, they are above all an epistemological critique, especially the articles from Horsthemke and Schäfer.

Against a non-essentialist posture assumed by ethnomathematics, Rowlands \& Carson (2002, 2004) and Horsthemke \& Schäfer (2006) advocate an essentialist position, based on the idea that although knowledge is constructed by humans, it remains beyond them. This is to say, there is some kind of invariant (an essence) which is repeated in all mathematical knowledge; whether this knowledge is developed in a Mongolian tribe or in a European university, the mathematics involved is the same. As the authors state: "[m]athematics is universal because, although aspects of culture do influence mathematics, nevertheless these cultural aspects do not determine the truth content of mathematics" (Rowlands \& Carson, 2002, p. 98).

The authors position themselves against the politicization of science, claiming that, "mathematics is a science, and its laws, principles, functions and axioms have little to do with issues of social justice" (Horsthemke \& Schäfer, 2006, p. 9). Or, as mentioned by Rowlands and Carson (2002) "rationality may be the preserve of an oppressive cultural system but that does not necessarily mean that rationality is in itself oppressive" (p. 82). Represented very strongly in this sentence is the idea that rationality exists per se, i.e., as something disconnected from the social and political environment. In that sense, mathematics is taken by the authors as a piece of truth and neutral knowledge that could be used for good or evil, although mathematics itself is free from judgement: "the odious use of something does not make that something odious" (p. 98).

These authors embraced academic mathematics as a universal human good; shared by all people and considered to be one of the biggest achievements of mankind. This universal knowledge is presented as being the climax of a human evolution, and clearly more precious than others: "[t]he reason we are attempting to 'privilege' modern, abstract, formalized 
mathematics is precisely because it is an unusual, stunning advance over the mathematical systems characteristic of any of our ancient traditional cultures" (Rowlands \& Carson, 2004, p. 331).

Finally, the authors adopted an epistemological position in which the genesis and consolidation of knowledge must be understood by analysing the internal logic of that knowledge and its pragmatic value, suggesting that social and political aspects have no influence in that genesis:

$[\mathrm{M}]$ odern conventions of mainstream mathematics have become 'privileged' (i.e. accepted by the world's mathematical community and numerous secular societies) for reasons that have little if anything to do with the politics of nations or ethnic groups, but have much to do with their pragmatic value. (Rowlands \& Carson, 2004, p. 339)

\section{Educational criticisms}

The catalyst for the educational critique developed by Horsthemke and Schäfer is the way the application of ethnomathematical ideas into South African schools contributed not to the inclusion, but to the exclusion of children. Ten years before, Skovsmose and Vithal (1997) had developed the same critique, although in a more constructive way. They called our attention to the way ethnomathematical ideas are implicated in schools of countries suffering from ethnic and racial tensions. In the case of South Africa, we can see how those ideas contributed to the creation of a lighter mathematical curriculum (based on students' backgrounds) for those students considered 'ethnic'2. As a consequence of these politics, those students were systematically excluded from access to academic mathematics then aimed at the white student: "in South Africa bringing students' background into the classroom could come to mean reproducing those inequalities on the classroom" (p. 146).

This critique of the way ethnomathematical ideas in school could be inadvertently used to deny access to academic mathematics is also made by Rowlands and Carson. These authors emphasise the dangers involved in not considering formal mathematics as an important part of all students' education. According to the authors, it is formal mathematics that gives access to a privileged world, and that all students should know how to appreciate that knowledge:

There is every danger that mathematics as an academic discipline will become accessible only to the most privileged in society and the rest learn multicultural arithmetic within problem solving as a life skill or merely venture into geometric aesthetics. (2002, p. 99)

\footnotetext{
${ }^{2}$ Black students in the context of the apartheid regime.
} 
What the authors criticize is the idea that school learning should be centred in the development of local and practical knowledge of the students. According to them, such a utilitarian education will limit students' life chances. In this sense, the introduction of ethnomathematical ideas in school can function as a factor for exclusion, because whereas the students from the "dominant culture" continue to learn the academic mathematics that allows them to compete in a more and more mathematized world, students from other cultures will only learn a local and rudimentary knowledge that scarcely contributes to their emancipation. This tension reflects the ambivalence between the two functions of current education: globalization and diversity. In this sense, the authors defend a clear distinction between the local culture of a student, and the scientific and school culture: "to preserve American Indian cultures, African tribal cultures, traditional cultures of Asia and elsewhere, their uniqueness must be recognised, not collapsed into a dreary and illusory sameness with scientific culture" (2002, p. 91).

Rowlands and Carson are against the use of ethnomathematical knowledge in the classroom, arguing that there may be incommensurable ways of understanding and perceiving mathematics. It is that incommensurability that could make an artificial endeavour out of the attempt to articulate ethnomathematical knowledge with school knowledge. They argue that people can master more than one culture, and school should be the place where people have contact with the more universalized culture, that is, the Western culture.

Finally, Rowlands and Carson consider mathematics to be a foreign language to all students before they go to school. Contrary to the ethnomathematical stance which argues that students already have non-formalized mathematical knowledge before they start school, these authors argue that protomathematical knowledge is not important for learning school mathematics, because all students are equally positioned to learn new knowledge:

We go to great lengths to point out that children of traditional cultural backgrounds are probably not at any significant disadvantage when it comes to learning mathematics, since it is a 'foreign language' to all novices, regardless their cultural background. (2004, p. 335)

Skovsmose \& Vithal (1997) acknowledge the importance of ethnomathematical ideas for a critical mathematics education. They identify four trends in the ethnomathematical research, and stress that it is in the confrontation with school mathematical curriculum that ethnomathematics finds its greatest challenge, and also the possibility of critique. Firstly, the 
authors stress the fact that research in ethnomathematics does not usually specify much about the relation between culture and power. Secondly, they identify a problem with the definition of 'ethnomathematics', and pose the question: how can someone educated in formal mathematics identify other mathematics? According to them, ethnomathematics only makes sense through the perspective of academic mathematics. Thirdly, the authors argue that ethnomathematics lacks a critique about how mathematics formats reality (Skovsmose, 1994). Finally, as mentioned before, Skovsmose \& Vithal (1997) think it necessary to problematize the idea of students' background, and not just in terms of the actual culture of students, but also about the aspirations and desires that students have of emancipation. This is what they call the students' foreground, by which they mean: "the set of opportunities that the learner's social context makes accessible to the learner to perceive as his or her possibilities for the future" (p. 147). According to Skovsmose (1994), all the importance given to students' background could inhibit them from emancipation, and more attention should be paid to the opportunities that the social, cultural and political context could bring to students. By emancipation Skovsmose means the access to and participation in a world where mathematical knowledge is central.

\section{Some comments on epistemological criticisms}

Before entering into a discussion of the epistemological criticisms made of ethnomathematics, I take the position that the interpretation of ethnomathematics carried out by Rowlands, Carson, Horsthemke and Schäfer is misleading. These authors understand ethnomathematics as an ethnic or indigenous mathematics. In fact, there is a vast diversity of studies in ethnomathematics, and some of them assume that ethnomathematics research consists of understanding, with the tools of academic mathematics, the mathematical ideas of culturally distinct people ${ }^{3}$. In that sense, ethnomathematics is indeed the study of an 'ethnic' mathematics:

The prefix ethno refers to ethnicity, this is, to a group of people belonging to a same culture, sharing the same language and rituals, in other words, culturally well delineated characteristics so we can recognise it as a specific group. (Ferreira, 2004, p. 70 , my translation from Portuguese)

In this perspective, the educational implications of ethnomathematics are focused on "how to bring ethnic knowledge to the classroom to allow for a meaningful education; how to

\footnotetext{
${ }^{3}$ See, for instance, the work of Bill Barton, Sebastiani Ferreira, Paulus Gerdes and Marcia Ascher.
} 
establish the bridge between ethnic and institutional knowledge" (Ferreira, 2004, p. 75, my translation from Portuguese). But there are other ways of addressing ethnomathematics. For instance, D'Ambrosio (2004) clearly says that his "view of ethnomathematics tries to avoid confusing ethnomathematics with ethnic mathematics, as understood by many" (p. 286). That is why D'Ambrosio prefers to talk about an "ethnomathematics program", as something more than the study of the ideas and uses of non-academic mathematics. I understand this program as a radical one; in the sense that it endeavours to criticize, not just mathematics and mathematics education, but social orders and ideologies that feed our current world. As mentioned by D'Ambrosio (2004), "the ethnomathematical program focuses on the adventure of human species" (p. 286). Others like Knijnik (2004) and Powell \& Frankenstein (1997) also criticize the idea of ethnomathematics as an ethnic mathematics and have developed investigations where the theme of power and politics are taken seriously.

The epistemological discussion carried out by Rowlands, Carson, Horsthemke and Schäfer is an echo of a bigger philosophical discussion about the nature of knowledge that was intensively debated in recent decades under the label of "science wars". As with any philosophical question, there are different ways of analysing it, and everyone has the right to choose the one that better fits his or her interests. I shall not enter into such a discussion here; rather I just want to call attention to the pertinence of having philosophical thought in such discussions. In a philosophical line, in which we can include Nietzsche, Kierkegaard, Durkheim, Wittgenstein, Althusser, Foucault, Derrida, Lacan among many others representatives of continental philosophy, knowledge is perceived from a non-essentialist perspective, i.e., as something whose creation, maintenance, valorisation or disqualification has nothing to do with its intrinsic or essentialist value, but with the way knowledge is exercised, whether it is in a language game (Wittgenstein, 2002), in the webs of discursive modalities involving power relations (Foucault, 2004), or as an ideological interpellation (Althusser, 1994). The meaning and the knowledge we have of something is always contingent, full of historicity, and involved with power relations. As mentioned by Amâncio (2004) the idea of knowledge as something universal, with an existence per se, is itself a very ideologically loaded position. Hence, the important aspect of this epistemological discussion is less a discussion on whether knowledge is itself universal or situated. Rather, this discussion is concerned with matters as mentioned by Foucault (2004): what intentions, what politics, allow us to claim that some knowledge (like academic mathematics) is universal?

Therefore, if we take support from these philosophers mentioned above, the essentialist position of Rowlands, Carson, Horsthemke and Schäfer regarding mathematical knowledge is 
hardly sustainable. Against the idea that our words, texts, language or discourses describe some given reality (the 'truth' of things, the 'objective' world), authors such as Lacan, Derrida and Žižek argue that rather than just describing reality, our words constitute reality as such:

It is the world of words which creates the world of things. (Lacan, 2001, p. 155)

The outside, 'spatial' and 'objective' exteriority which we believe we know as the most familiar thing in the world, as familiarity itself, would not appear without the gramme. (Derrida, 1976, p. 42)

The discourse of ontology is thus sustained by an "indirect speech act": its assertive surface, its stating that the world "is like that", conceals a performative dimension, i.e., ontology is constituted by the misrecognition of how its enunciation brings about its propositional content. (Žižek, 1992, p. 114)

This is what in psychoanalysis is termed the performative power of the word: reality is something which is constituted, posited by the subject. When we say that the world is written in mathematical language-the idea that mathematics is everywhere-we are not asserting some ontological truth about the world or about mathematics, rather, it is by means of declaring it that the world becomes 'written' in mathematics. The truth claim of a statement cannot be authorized by means of its inherent content. The omnipresence of mathematics relies on its own act of enunciation. This is why Foucault says that the epistemological discussion should be centred not in finding the intrinsic truth of knowledge, but which are the positions of enunciation (the politics) that vouch for the veracity of some knowledge.

This same idea is also present in the way some ethnomathematics researchers understand mathematics. For instance, when Adam, Alangui \& Barton (2004) talk in terms of "recognis[ing] mathematics as part of their [students'] everyday life" (p. 332), we sense as if students already are using mathematics before they learn it in school: in school they just "recognize" it. However, I prefer to conceive this "act of recognition" as a performative one, in the sense that students do not recognize something that was always there, rather mathematics starts being there from the moment someone performatively asserts that what students were doing was mathematics.

The authors of the essentialist perspective position themselves as the guardians of academic mathematics that fuels this modern world, and which is seen as being superior to any existing society, "the beliefs and practices of other societies are epistemic and vertically inferior to our own" (Horsthemke \& Schäfer, 2006, p. 12). From their perspective, we are living the climax of a human evolution, in which academic mathematics is the substrate of a 
society based on humanistic ideals. This universal society is however problematic. Part of the research on ethnomathematics has been concerned to understand how these universal images of society are generated through history ${ }^{4}$. As mentioned by the Spanish philosopher Lizcano Fernández (2004), the idea of such a universal society was possible through "the development of a set of formalisms characteristic of a peculiar way that has a certain tribe, of European origin, to understand the world" (p. 126). In other words, the universal society (capitalist society) based on universal knowledge (mathematics and science) suggested by Rowlands, Carson, Horsthemke and Schäfer is a very particular way of understanding time and space, of classifying and ordering the world, of understanding economic and social relations. In short, of conceiving what is possible and impossible to think and do.

\section{Criticisms and contradictions of the educational implications of ethnomathematics}

\section{On the neutrality of school mathematics}

One of the claims made by Rowlands and Carson (2002) and Horsthemke and Schäfer (2006) has to do with the alleged neutrality of school mathematics. As we saw, these authors defend the idea that every student is from the beginning equally positioned to learn this completely new language called mathematics. Their arguments are based on the idea that mathematics is a universal body of knowledge, accessible to every human being through cognitive work. We can glimmer in these positions the way psychology continues to be a main influence in the field of mathematics education. Despite all the research done in the last twenty years criticizing the idea of the child as a "cognitive subject" (Valero, 2004), as an idealized student willing to learn and reduced to his cognitive dimension ${ }^{5}$, the prevailing theoretical ideas in mathematics education continue emphasizing the psychological dimension of the student (Lerman, 2000; Valero 2004).

On the other hand, Rowlands and Carson (2002) and Horsthemke and Schäfer (2006), and also Skovsmose and Vithal (1997) to some degree, understand school as a place for emancipation, in the sense that it is through school that someone can become a fully active and participative member of our society. This approach to mathematics education is in line with the discourse underlying most mathematics education research, which establishes mathematics as one of the biggest achievements of humankind, considered to be the main pillar of our technological society, and an indispensable tool to becoming an active participant

\footnotetext{
${ }^{4}$ See, for instance, the book edited by Powell \& Frankenstein (1997), which collects a set of articles in which these ideas are deconstructed.

${ }^{5}$ According to Valero (2004), this research approach conveys neoliberal perspectives of school, by putting the emphasis on the individual subject barred from the social and political context in which the learning occurs.
} 
in a more and more mathematized world. Learning mathematics is a critical requisite to being a citizen. According to the National Council of Teachers of Mathematics (NCTM) (2000), it gives power to participate in the world.

Using the theoretical framework developed by Skovsmose \& Valero (2008) to deal with the issue of power in mathematics education, we can say that mathematics education can empower people through the intrinsic characteristics of mathematics itself (logical thinking, abstraction); by providing students with psychologically meaningful experiences (solving problems, metacognition); by enhancing the relation between cultural background and foreground therefore allowing students to learn 'in context' (connection between everyday practices and school mathematics; providing opportunities to envision a desirable range of future possibilities); and finally, students can get empowered through school mathematics by exploring situations of "mathematics in action", which makes visible the way mathematics formats reality (exploring real mathematical models in a critical way). What is missing in these four perspectives of conceiving the way mathematics empowers people is the fundamental one-mathematics empowers people not so much because it provides some kind of knowledge or competence to them, but because it gives people a value. Mathematics empowers people because it is posited as a socially valuable resource.

To my knowledge, it was Shlomo Vinner (1997) who, within mathematics education, first addressed schools as credit systems. According to him,

students have very good reasons to study mathematics. It is not the necessity of mathematics in their future professional life or their everyday life. It is because of the selection role mathematics has in all stages of our educational system. (p. 3)

Contrary to the NCTM assertion that mathematics empowers people because it provides some kind of knowledge or competence to them, Vinner argues that this empowerment has instead to be understood in the field of value. Mathematics allows students to accumulate credit in the school system that will allow them to continue studying and later to achieve a place in the sun. Mathematics empowers people because it is posited as an economically valuable resource. As Bishop \& Forgasz (2007) put it, "in every country in the world mathematics now holds a special position, and those who excel at it or its applications also hold a significant positions in their societies" (p. 1149).

This political dimension of mathematics education has been addressed within the research community. For instance, Skovsmose (2005), in his latter writings, moves towards a more 
critical view of the role of school in our society. In particular, the role of school mathematics. According to Skovsmose, schools can represent the opportunity to succeed in life, or they can represent the place that marks you as "disposable", and mathematics is right at the core of this selective process, as has been shown by research in mathematics education (e.g. Atweh, Forgasz, \& Nebres, 2001; Burton, 2003; Secada, Fennema \& Byrd, 1995; Valero \& Zevenbergen, 2004; Bishop \& Forgasz, 2007). We have today studies which analyse the way school mathematics functions as a gatekeeper (e. g. Stinson, 2004), is involved in processes of social exclusion (e. g. Knijnik, 1993), fosters social injustice (e. g. Gutstein, 2003), or, within a Foucaultian perspective (Popkewitz, 2004), how school mathematics constructs a set of learning standards that are more closely related to the administration of the children than with an agenda of mathematical learning.

These studies allow us to understand how school mathematics is not a neutral subject, equally available to everyone. At the same time, they invite us to posit the importance of mathematics not so much in terms of knowledge and competences, but in terms of accreditation through a credit system conveyed by school. However, despite the awareness that school mathematics performs a strong economical and political role, there is a lack of studies in mathematics education research that seek to understand school mathematics as part of dominant economical systems such as capitalism (Gutiérrez, 2007; Pais, 2011). Indeed, elsewhere (Pais, 2011), I argue that there is a tendency to face the problem of equity as being strictly from the domain of mathematics education understood as the developing of better ways to teach and learn mathematics in school environments (Cobb, 2007; Silver \& Herbst, 2007). Gates \& Zevenbergen (2009) state that "mathematics and social justice has been the focus of much research-however this has largely focussed on such issues as the process of learning, the content of the curriculum and its assessment" (p. 162). They also make a very suggestive point. They argue that it is common in mathematics education research to discard such 'political' questions since it is not the responsibility of mathematics education to address them (p. 165). This picture is worrisome if we accept that the school system, as a rule, is overdetermined by late capitalist economics and ideology (Althusser, 1994; Jameson, 1991). ${ }^{6}$

\footnotetext{
${ }^{6}$ Contrary to the assumption defended by many economists (most notably Daniel Bell's post-industrial society) that we have arrived at a new type of society, where the new social formation in question no longer obeys the laws of classical capitalism, "late capitalism" (Jameson, 1991) signals instead that this 'new society' is a purer stage of capitalism than any of the moments that preceded it. In this sense, every position on postmodern in culture "is also at one and the same time, and necessarily, an implicitly or explicitly political stance on the nature of multinational capitalism today” (Jameson, 1991, p. 3). Frederic Jameson, together with Slavoj Žižek, are arguably the two most powerful contemporaneous theoreticians interested in scrutinizing the ways in which capitalism has become the "concrete universal", as Žižek (2004, p. 3) calls it, of our historical époque: "what this means is that while it remains a particular formation, it overdetermines all alternative formations, as well as all noneconomic strata of social life". It is in this sense that we argue that education is overdetermined by
} 
Ethnomathematics carries within it a critique of school mathematics. ${ }^{7}$ D'Ambrosio (2003), for instance, compares the current school with a factory, where people are components of big machinery that aims for uniformity. Others, such as Powell \& Frankenstein (1997) or Bishop (1995), try to understand how mathematics in society conveys hegemonic discourses and oppressive educational practices that promote exclusion and domination. In school, as mentioned by Rowlands and Carson $(2002,2004)$, we are introduced to a certain society. And if we are satisfied with our current society, as apparently is the case of Rowlands, Carson, Horsthemke and Schäfer, then we must prepare students the best we can to be full members of that society. But authors of some of the studies in ethnomathematics do not share this optimistic view of current society. ${ }^{8}$

Society should be problematized, and not taken for granted, especially when we are aware of the economical politics based on market priorities, and all the ideologies that fuel our way of living. What does it mean to educate people to be participative, active authors in a more and more merchandized society? Do we all want "schooling to serve the needs of industry and commerce?" (Rowlands \& Carson, 2002, p. 85). Hence, a problematization of society, and the role of school in society is, in my opinion, a priority in a research program like ethnomathematics. But that is far from happening.

\subsection{School knowledge is a particular form of knowledge}

Critics do not deny the existence of different cultures, where different knowledge has been developed. However, they clearly say that this knowledge is inferior to the knowledge developed by the dominant Western culture, since it is the latter that allows people to become full citizens in current society. In order to allow everyone this opportunity, school should provide students with this universal knowledge, the base of our high-tech society. This position does not assume that other knowledge and practices different from the ones conveyed by school curriculum are not important and should be forgotten. On the contrary, they acknowledge the importance of this different knowledge. But they argue that it should remain in the places where it makes sense, and not in school designed to be the place for learning the official knowledge. This official mathematical knowledge is presented as being universal in the sense that it can be learned without context.

\footnotetext{
capitalism.

${ }^{7}$ See, for instance, the work of Ubiratan D'Ambrosio, Gelsa Knijnik and Alexandrina Monteiro.

${ }^{8}$ In Powell \& Frankenstein (1997) we can find a set of articles that articulate a critique of mathematics with a critique of society. See also the most recent writings of Ubiratan D'Ambrosio (for instance, D'Ambrosio, 2007) where he developed a social critique, based on the idea of peace.
} 
Although this critique may sound like a prepotent and exclusionary act, it calls attention to some problematic theoretical assumptions in ethnomathematics research. If we consider the research on the socio-cultural aspects of knowledge and learning we can assert that all knowledge is eminently situated in the places where it is used, whether these places are a workplace or an indigenous community (Lave, 1988). The meaning of some practice and knowledge is deeply involved in the community of practice where it is exercised and developed (Lave \& Wenger, 1991). There is no guarantee that people transfer knowledge from one practice to another without some kind of 'misrecognition'. School mathematics, although it can explore 'real' situations, will always be school knowledge, learned in a specific place called school where students are not necessarily concerned with learning. ${ }^{9}$

Based on Wittgenstein's philosophy, some researchers (e.g. Gottschalk, 2004) have argued that meaning is just possible from the point that we get appropriated of the rules of the game, of the constituent language that allows us to speak with meaning. In the case of mathematics, only when the pupils get a set of (mathematical) rules can they play the game of school mathematics. In school, we learn "conventional techniques". The constructivist idea that a student constructs the meaning by himself is, if we take the work of Wittgenstein seriously, a fallacy. In school, students get enculturated into a set of conventions that allow them to be part of that community. Therefore we can say that there is no emergence of meaning without the transmission of a set of conventions and rules; that is, without the appropriation by the student of the conditions of meaning that will determine his thought.

We can then assert that knowledge is not independent from the contingency of its emergence. When we bring local knowledge to school, whether it is some practical knowledge or 'ethnic' knowledge, what happens is a decontextualization of the conditions that justify the emergence and use of this knowledge. If knowledge and learning are not purely cognitive processes happening in the heads of individuals, but socially situated practices, deeply connected with context, then it is not without trouble that we can assert the advantages of linking local and school knowledge and practices. Like Rowlands and Carson said, there can be incommensurability between these two dimensions.

When some researchers went to indigenous tribes to research how indigenous people use mathematics, for instance, in the construction of houses, and then brought this knowledge to the school system in order to take advantage of it to teach them the school mathematics knowledge, something was already lost. The construction of houses in a tribe is a communitarian activity, involving rituals and knowledge only identified as being

\footnotetext{
${ }^{9}$ For a clear understanding of how students in school engage not in learning but in passing, see Baldino \& Cabral (1998).
} 
mathematical by people outside the community. When this knowledge is brought to school to teach, for instance, the relation between the sides of a rectangular triangle, students are in a completely different setting and only in a forceful and artificial way can we say that the previous knowledge about house construction will be helpful to learn the Pythagorean theorem in a formalized or scholarized way. If, on the other hand, we take the option of incorporating this knowledge into the school curriculum by itself ${ }^{10}$ (i.e., as construction of houses as it is done in the indigenous community) we end up, as the critics notice, allowing students only a local and practical knowledge that will only be useful to them in the context of the community, which has other ways of transmitting this knowledge that has nothing to do with school. D'Angelis (2000) argues that an indigenous school should be concerned in teaching not what has always been taught inside the community with their own methods, but what indigenous people want: mathematics and language of the white people (as is noted by Scandiuzzi, 2004, p. 373). According to D'Angelis, the content of the school subjects should not conflict with the proper and particular forms of education characteristic of some community (whether this community is an indigenous village or a work place). That is, school should not take spaces that belong to other forms of culture, by scholarizing those contents that are specific to a non-school environment. This will to bring to school local knowledge can entangle a prejudice, since it seems like we are avoiding a prejudice-the one that says that knowledge developed by people in their local practices is not knowledge-by fuelling another -the one according to which local knowledge is only considered to be true knowledge if it is taught and evaluated in school. The result of such a strategy of bringing local knowledge to school, by transforming it in curriculum content, takes the risk of not being an indigenous school but a "westernized" indigenous school.

Particularly important was the eye opening work done by Dowling (1998), who revealed some of the pitfalls of what Bernstein called recontextualization. For him, "the recontextualization of everyday life material into the curriculum ends up by being neither 'real maths' nor 'real life"' (Evans, 1999, p. 27). Something is always already lost when we transpose some everyday activity into school, and vice-versa. What Dowling (1998) calls the myth of participation-the idea that mathematics is a necessary feature of everyday practicesends up creating a school curriculum where mundane activities are mythologized in a way that privileges mathematical rather than everyday principles. That is to say, everyday activities, in order to be introduced in school, need to be amputated of all the complex vicissitudes which

\footnotetext{
${ }^{10}$ This is possible in the context of indigenous schools that have been developed very strongly in Brazil during the last ten years.
} 
makes them what they are. This amputation-the result of casting the mathematical gaze onto public domains-privileges what Dowling (2001, p. 22) calls the "esoteric domain", while, at the same time, concealing the purely fictional status of the importance attributed to mathematics.

It would seem that it is not intrinsically "beneficial" to bring local knowledge to school. On the one hand we have the position defended by most of the ethnomathematics educators that ethnomathematical knowledge could help students understand the formal mathematics, by incorporating this knowledge in the curriculum. On the other hand, we have researchers that challenge this idea of adapting or incorporating local knowledge into the curriculum. According to them, school should be reserved for the learning of the official knowledge, and leave the local knowledge developed in the communities. There is no easy way out of this paradox: whether school should be reserved for the learning of the "globalized" knowledge allowing everyone to participate in our high-tech world, or a school that incorporates diversity but runs the risk of domestication of the Other.

\section{Ethnomathematics in school settings: dealing with contradictions}

In response to the article of Rowlands \& Carson (2202), Adam, Alangui \& Barton (2003) identify several possibilities for an ethnomathematical curriculum. Ethnomathematics can appear in schools as an approach to mathematics; as a particular content distinct from the conventional mathematical concepts taught in schools; as a stage in the progression of mathematical thinking; as awareness that classrooms are situated in a cultural context. However, the approach favoured by these authors is:

An integration of the mathematical concepts and practices originating in the learners' culture with those of conventional, formal academic mathematics. The mathematical experiences from the learner's culture are used to understand how mathematical ideas are formulated and applied. This general mathematical knowledge is then used to introduce conventional mathematics in such a way that it is better understood, its power, beauty and utility are better appreciated, and its relationship to familiar practices and concepts made explicit. In other words, a curriculum of this type allows learners to become aware of how people mathematise and use this awareness to learn about a more encompassing mathematics. (Adam, Alangui \& Barton, 2003, p. 332)

This approach, concerned in establishing a "bridge" between local and school knowledge, is prevalent in ethnomathematics research, as we understand by reading the book entitled Ethnomathematics and Mathematics Education (Favilli, 2007), which collects research in 
ethnomathematics from all around the world as a result of the works presented and discussed in the Discussion Group 15 at the $10^{\text {th }}$ International Congress in Mathematics Education (ICME10). Many authors of the studies in ethnomathematics advocate the importance of bringing to the classroom the local knowledge of students. This "making the bridge" between local mathematical knowledge and school mathematics knowledge is seen as a way of valorising students' cultures, and at the same time allowing students to better understand the formal mathematics from their own not yet formalized knowledge. However, this approach is not consensual among ethnomathematical researchers.

To speak to one of the criticisms made by Rowlands, Carson, Horsthemke and Schäfer regarding the use of ethnomathematical knowledge in regular schools, we can identify a contradiction in how ethnomathematicians understand its pedagogical implications. On the one hand, as mentioned before, some researchers, such as Adam, Alangui \& Barton, (2003), defend the idea of using students' ethnomathematical knowledge to construct a bridge for the learning of formal mathematics. But, on the other hand, researchers like Knijnik (2004) clearly state that: "it's not a matter of establishing connections between school mathematics and mathematics as it is used by social groups, with the purpose of achieving a better learning of school mathematics" (p. 228).

Implicit in these two views, is the way researchers understand the role of mathematics and school in our society. The problem with the first one, characterized by the "bridge metaphor", is the reinforcement of the hegemony of school mathematics because the Other is valorised only as a way to achieve the true knowledge. Thus, it contradicts the critique that ethnomathematics makes to the hegemony of academic mathematics. The same problem identified by the critics regarding the valorisation of background instead of the foreground, is also raised by Knijnik (2004), Monteiro (2004) and Duarte (2004). These authors raise questions about the usually folkloric way ethnomathematical ideas appear in the curriculum. According to them, the use of local knowledge as a curiosity to start the learning of school mathematics could be the cause of social inequalities, as mentioned by the critics.

Duarte (2004) argues that there is an abundance of cases in ethnomathematics research where the generous act of integrating local knowledge into the school curriculum ends up contributing to its marginalisation. The author uses the expression "include to exclude" to illustrate how the result of some inclusive actions consists in accepting diversity but keeping it at a safe distance by means of integrating different cultures not in their totality, but as a curiosity, an illustration, a "starter" to the real mathematics. According to her: 
This distance has been kept when, in the curriculum, in the task of rescuing knowledge from subordinated groups, we treat them as something exotic, as a souvenir or simply as starting points to the academic knowledge. In this sense, rescuing popular savoir becomes a trap that ends up producing and reinforcing social inequalities. (Duarte, 2004, p. 188, my translation form Portuguese)

But truly to include ethnomathematical ideas in the curriculum is no less problematic. If we focus on a regular school, and take into account its role in preparing students for a globalized market orientated society, with all the pressure to learn the mathematics of the standard curriculum that will be essential to students' approval in the high stakes tests, we can ask ourselves if there is a place for ethnomathematical knowledge (or other local, non scholarly knowledge)? My opinion, according to my review on ethnomathematical research, is that these educational implications of ethnomathematics (in a regular school) end up being co-opted by a school that, as Rowlands, Carson, Horsthemke and Schäfer would agree, is worried with the uniformization of knowledge. In that sense, I agree with them, and also with Skovsmose and Vithal when they say that focusing the learning of mathematics on students' local knowledge could be a factor for social exclusion. But the problem is not just in ethnomathematics, but in school itself. Monteiro (2004), a Brazilian ethnomathematician, poses the definitive question: "Is it possible to develop ethnomathematical work in the current school model?" (p. 437, my translation from Portuguese). According to her, an education based on ethnomathematical ideas demands a deep transformation in school organization.

\section{A critical approach to diversity and schooling}

\section{A typical example of the "bridge metaphor"}

In the remaining pages I will use Slavoj Žižek's critique of multiculturalism (Žižek, 1992, 2009) to analyse how research on ethnomathematics can convey ideologies contrary to the ones it praises. I will look at two articles published in the book edited by Franco Favilli, and mentioned previously, which I consider typical of the "bridge metaphor" approach in the way ethnomathematics research conceives its educational implications. The first one (Favilli \& Tintori, 2007) is part of a bigger project called Innovation in Mathematics Didactics and Technological Aids for Multicultural Context with Immigrant and Minority Pupils, a three year trans-national project funded by the European Union. In this particular article authors present considerations made by mathematics teachers and their pupils after completing an experimental, intercultural and interdisciplinary didactic proposal. The second one (Fiorentino \& Favilli, 2007) consists of the exploration of an ancient Inca mathematical artefact called 
yupana, in an electronic version. The aim of the authors is to explicitly make the bridge between several dimensions that opponents are unlikely to see as being compatible: "link tradition and modernity, indigenous and scientific knowledge, poor and rich cultures" (p. 49).

In both articles authors note that classrooms are now, more than ever, multicultural sites; implying a need for a multicultural approach by the teacher. They also note that in such multicultural classrooms pupils bring extraordinarily diverse cultural experiences in which we can identify mathematical knowledge apart from mathematical programs that inform school work. This idea, however, contrasts with the example Favilli \& Tintori (2007) explore with the teachers-the construction of a zampoña (Andean flute or Pan Pipes)-since no evidence in the article is provided that those Italian students were descended from South American people. Although we can accept the argument that all students should be confronted with practices and knowledge from different cultures, the idea of bringing to the classroom local knowledge of students is not visible in this example. The construction of the zampoña served as background to the learning of curricular mathematical content like proportionality, functions and the concept of ratio, and, at the end, "results in the test that followed were quite good" (p. 46, speech of one of the teachers).

What is the problem with this almost idyllic example of a multicultural approach? Apparently researchers and teachers are valorising other cultures, the manual work, the discussion among students, and the curricular mathematical content. No major problems were raised either by students or by teachers, at least from the transcription of their opinions present in the article. But are they really "valorising" other cultures? What was the role of the Andean zampoña in these mathematical classes? Do teachers explore with students the Andean understanding of music and its meaning in the Andean culture? Do students (or teachers and researchers) acknowledge the social context involved in the local construction and use of a zampoña? For instance, the fact is that in such a rugged environment as the Andes, the sense of community is absolutely integral to the concept of survival, and the way Andean people play the zampoña reflects the community spirit. Is this spirit compatible with the realization of standard tests designed to evaluate individual achievements of mathematical knowledge raised by the zampoña exploration in the classroom?

In Fiorentino \& Favilli (2007) the example changes-now the didactical tool is a reinvented yupana, an Inca abacus. The idea of the authors is to "reinvent the yupana to obtain an easy and solidly founded didactic tool" (p. 55). They construct an electronic yupana aimed at providing a classical base 10 numeric feedback by continuously showing all relevant numeric information along the border. As far as I know, up to now nobody has been able to completely 
explain the meaning of the Inca geometrical tablets ${ }^{11}$. I suggest that the difficulty in deciphering these tablets is due to the fact that it is not just a mathematical matter. It involves a deep contextualization of the social, political, economical and religious system in which these artefacts made sense. To transmit the idea to students that what Inca people did is similar to what they are doing in modern classrooms could end up reducing the meaning of yupana in the Inca culture for the purpose of learning school mathematics.

I argue that this "microscopic" exploration of a cultural artefact serves as no more than a "motive" or an "illustration" to learn the mathematics of the official curriculum. Culture is reduced to a musical object that, for that purpose, could be any other. The Other is desubstantialized (Žižek, 2009), deprived of all the social, political, economical, or religious dimensions that characterized their culture, when it is presented in the classroom as a folkloric example that neglects all the complexity that surrounds it. It is just a way of teaching mathematics.

\section{Multiculturalism within capitalism}

These examples make visible the sometimes shallow way in which the educational implications of ethnomathematics are thought and practiced. It becomes clear in these examples how powerful ideas, such as ethnomathematics' critique of academic and school mathematics, end up being co-opted by school practices, which do not sit well with the broader ethnomathematics critique of schooling. As we saw, the ethnomathematics program encompasses a critique of society and school. Thus, it is not enough to have a didactical approach to ethnomathematics or schools. The insertion of ethnomathematical ideas into regular schools needs to be theorized. In particular, I argue that we need studies that extol not so much the potentialities and benefits of multicultural education, but above all the obstacles and the inconsistencies involved in such education.

According to Žižek (1997), such inconsistencies make visible the way ideology functions today. Ideology becomes effective precisely in the discrepancy between the official discourse-which exalts teachers to work with students' topics of ethnomathematics, and schools to promote cultural diversity-and its actualization into a "life-world context" (p. 93). What, at the level of the enunciated content, runs smoothly-practically nobody within ethnomathematics research contests the importance of cultural diversity-when actualized in a specific practice (in our case, school practice) often encounters a series of obstacles which ends up perverting the core goal of ethnomathematics. This way, a potentially emancipatory

\footnotetext{
${ }^{11}$ See http://www.abc.net.au/science/news/stories/s1036168.htm for a discussion of this issue.
} 
enterprise such as ethnomathematics is transformed into what Žižek (1997, p. 76) calls an "inherent transgression". That is, a change that is already predicted and even promoted (many curricula around the world already refer to the importance of bringing local cultures into the classroom) by the same system it tries to change.

This critique is not new. Already Paulo Freire, four decades ago, called our attention to what he called "superficial transformations": "the elites are anxious to maintain the status quo by allowing only superficial transformations to prevent any real change in their power of prescription" (1998, p. 508). Žižek gives us theoretical tools to understand this process of domestification (Pais, Fernandes, Matos \& Alves, 2011) within the broader fields of politics, namely, within the hegemonic capitalist economics and ideology.

Although I will not have the opportunity to address in this article the full potentiality of Žižek's political analysis of multiculturalism as the cultural logic of multinational capitalism (2009), I shall call readers' attention to the way in which multicultural ideas can convey the spirit of "late capitalism" (Jameson, 1991). As I mentioned, today ideology functions by means of making effective what officially conceals. In our case, we can say that other cultures are allowed to come into school, as long as they become part of the school culture. The system satisfies the societal demand of a meaningful education for all, by importing local cultures into the curriculum, while assuring that such "insertion" will not actually change any of the core features of the school system. It is in this sense that Žižek says that today's capitalism needs to promote constant reforms and innovations to conceal the crude reality that core choices (such as a radical transformation of the school system as advocated by some ethnomathematicians) are not available. As Žižek (2006, p. 348) puts it, "[t]his appearance of choice, however, should not deceive us: it is the mode of appearance of its very opposite: of the absence of any real choice with regard to the fundamental structure of society".

Without a doubt, we-fed, washed and scented people-live in a world where the choices available are numerous, in virtually all dimensions of life. Regarding education and ethnomathematics, there is already a considerable array of didactical proposals aimed to nurture a multicultural education. Indeed, if we take the various texts listed in the website of the Ethnomathematics Digital Library (a program aimed to develop resources for education and learning) we could without difficulty prepare a full mathematical curriculum around the exploration of local uses people do of mathematics. As it was mentioned by one of the reviewers of this text, in South Africa a whole knowledge industry is developing around the idea of Indigenous Knowledge Systems of which ethnomathematics is one component. The power of capitalism to produce variety is at work in the educational applications of 
ethnomathematics. It is in this sense that Jameson (1991) calls our attention, in a somehow severe way, to the dangers of what he calls "neo-ethnicity": "Ethnicity in the postmodern, in other words-neo-ethninity-is something of a yuppie phenomenon, and thereby without too many mediations a matter of fashion and the market" (p. 341).

This incorporation of ethnomathematical ideas into capitalist dynamics is made possible through the deployment of an ideological injunction where we are willing to accept the Other deprived of its otherness (Žižek, 1992). That is, we are willing to accept the Other as long as it fits into our symbolic order, ${ }^{12}$ as long as it is kept at a safe distance, the distance that prevents us from reaching its non symbolic dimension. I love the Other (the poor, the indigenous) precisely because he is poor, oppressed, and utterly helpless, needing protective care. Žižek puts this way:

It is easy to love the idealized figure of a poor, helpless neighbour, the starving African or Indian, for example; in other words, it is easy to love one's neighbour as long as he stays far enough from us, as long as there is a proper distance separating us. The problem arises at the moment when he comes too near us, when we start to feel his suffocating proximity-at this moment when the neighbour exposes himself to us too much, love can suddenly turn into hatred. $(1992$, p. 9)

This critique, as we saw in the beginning, is also made by Kincheloe and Steinberg (2008) regarding indigenous education, and Dowling (1998) regarding ethnomathematics. When we claim that we must 'give voice' to the oppressed (poor students, ethnic students, minorities, and so on), we always take the risk, behind the appearance of a legitimate will for valorising the voices of oppressed people, of stipulating how this voice should be, by positing the Other in our symbolic order, constructing him as innocent, in need of help, oppressed people who are seen as victims of our consumerist and racist society. They have voice as long as their voice is the voice of the oppressed, the voice asking for help, the voice we expect to hear. When the poor student admits that he just wants to be rich, or the 'ethnic' student says that he only wants to learn the mathematics of the white people, we feel deceived, because we encounter the real Other. It is as if there was an underlying desire to keep someone in the status of a victim, so that we can enact in ourselves the desire for helping: "the saintly person uses the suffering of others to bring about his own narcissistic satisfaction in helping those in distress" (Žižek, 1997, p. 101). This "saintly" spirit, in all similar to the one of charity and philanthropy, completely endorses the spirit of capitalism. It allows people to ease their

\footnotetext{
${ }^{12}$ I am referring to what Jacques Lacan (2001) called the Symbolic: the intersubjective symbolic network that structures our sense of reality.
} 
consciousness, while at the same time assures that no fundamental change in schools or in the economical organization of society occurs.

I want to make clear that I don't consider the kind of educational approach promoted by the example I explored to be representative of the way ethnomathematics conceives its educational implications. However, I do not see it as an extreme case either. On the contrary, situations such as this one-the application of ethnomathematical ideas into formal educational spaces without a critical reflection on schooling and society-are common in ethnomathematical research, as we saw previously. On the other hand, by criticizing the insertion of cultural artefacts into regular mathematical classrooms I do not pretend to diminish the value of the research or the goodwill of the researchers and teachers who are attentive to the diversity of mathematical practices. Both the zampoña and the electronic yupana can be good didactical tools (such as modern calculators, polydrons, 24game or other of the many currently available tools to learn mathematics), depending on the way they are used in the classrooms. What I want to highlight is the assumption that by simply using these tools, presented as "multicultural" artefacts, we guarantee the promotion of what authors call a multicultural education. In fact, I argue that such activities, disguised as multicultural, end up conveying the idea that culture can be reduced to the exploration of an artefact, as, when we visit some foreign country, the idea that we get in touch with local culture by seeing some folkloric dance. Culture and cultural diversity are something much more complex and, sometimes, what we call local or foreign cultures are something much closer to our own culture than we are willing to accept.

\section{Conclusion}

In this article I have tried to promote a deeper theoretical approach to the pedagogical implications of ethnomathematics. I have confronted some of the most important criticisms made of current research in ethnomathematics, showing that the educational proposals raised by ethnomathematics research are not consensual even among ethnomathematicians. Where some see as unproblematic the "making of the bridge" between local and school knowledge, others criticize this learning strategy, claiming a place for a more serious understanding of the role of school and how local knowledge is inserted into it.

One of the main features of ethnomathematics research consists in developing a critique of what is accepted as being mathematical knowledge, by the confrontation of knowledge from different cultures. The existence of different ways of dealing with quantity, space and patterns are now well documented, and it is not possible to deny them. But to pass from this 
acknowledgement to the aim of inserting it in a school setting in order to be disseminated through school education is problematic because schools are not open spaces of shared knowledge. On the contrary, curricular changes, especially when the subject is mathematics, are very strict. Whether we choose to use this different knowledge as a curiosity, an illustration or a 'starter' to the formal mathematics of the curriculum, or to develop a curriculum where one of the topics is local knowledge per se, the result may not be students' emancipation or the valorisation of different cultures. On the contrary, the process of bringing diversity and ethnomathematical ideas into the classroom may end up conveying practices opposed to the benevolent multicultural ideas these researchers want to enforce, by promoting a desubstantialized view of Other's culture.

Therefore, unlike D'Ambrosio, I do not think that the educational implications of ethnomathematics are obvious. Although I do believe in the good will of teachers, politicians or researchers in trying to bring to school knowledge and practices different from the ones conveyed by the official school curriculum, I have called attention to the sometimes naïve way in which this bridging is made. I challenge research in ethnomathematics to develop a stronger theoretical analysis of the social and political strands within which its research is carried out. Confronting different criticisms and contradictions of ethnomathematics, and bringing the work of the Slovenian philosopher Slavoj Žižek to the field, was my way of contributing to this theoretical discussion. It is my contention that such a discussion cannot avoid addressing the educational implications of ethnomathematics in the context of the two antagonistic functions of education in current societies: the necessity to preserve knowledge and practices from different cultures and, at the same time, the concern with the appropriation by all people of the global knowledge conveyed by school. Paying attention to the contradictions involved in this antagonism is needed so that well intentioned actions do not end up having results opposite to their aims. Ethnomathematics as a research field takes advantage by rejecting any dogmatic position and being aware of contradictions implicated in their pedagogical aims.

\section{Acknowledgements}

This article is part of my $\mathrm{PhD}$ project, supported by the Foundation for Science and Technology of Portugal, grant SFRH/BD/38231/2007. It is also part of the Project LEARN funded by the same foundation (contract PTDC/CED/65800/2006). I am grateful to Maria do Carmo Domite who received me during the year of 2008 in São Paulo, and introduced me to a field of literature and research without which this article wouldn't be possible. 


\section{References}

Adam, S., Alangui, W. \& Barton, B. (2003). A comment on: Rowlands and Carson "Where would formal, academic mathematics stand in a curriculum informed by Ethnomathematics? A critical review". Educational Studies in Mathematics, 52, 327-335.

Althusser, L. (1994). Ideology and ideological state apparatuses. In S. Žižek (Ed.), Mapping ideology. London, UK: Verso.

Amâncio, C. (2004). Da universalidade [Of universality]. In G. Knijnik, F. Wanderer, \& C. Oliveira (Eds.), Etnomatemática: Currículo e formação de professores [Ethnomathematics: Curricula and teacher education]. Santa Cruz do Sul, RG: Edunisc.

Atweh, B, Forgasz, H. \& Nebres. (Eds.) (2001). Sociocultural research on mathematics education: An international perspective. Mahwah, USA: Lawrence Eribaum.

Baldino, R., \& Cabral, T. (1998). Lacan and the school's credit system. In A. Olivier \& K. Newstead (Eds.), Proceedings of 22nd Conference of the International Group for the Psychology of Mathematics Education (PME22) (Vol. 2, pp. 56-63). Stellenbosch, South Africa: University of Stellenbosch.

Barton, B. (1996). Making sense of ethnomathematics: Ethnomathematics is making sense. Educational Studies in Mathematics, 31, 201-233.

Bishop, A.J. (1995). Western mathematics: The secret weapon of cultural imperialism. In B. Ashcroft, G. Griffin \& H. Tiffin (Eds.), The post-colonial studies reader. London, UK: Routledge.

Bishop, A. J., \& Forgasz, H. J. (2007). Issues in access and equity in mathematics education. In F. K. Lester Jr. (Ed.), Second handbook of research on mathematics teaching and learning. Charlotte, NC: Information Age Publishing.

Borba, M. (1990). Ethnomathematics in education. For the Learning of Mathematics, 10(1), $39-43$.

Burton, L. (Ed.) (2003). Which way social justice in mathematics education? Westport, CT: Praeger.

Cobb, P. (2007). Putting philosophy to work: Coping with multiple theoretical perspectives. In F. Lester (Ed.), Second handbook of research on mathematics teaching and learning. Charlotte, NC: Information Age Publishing.

D’Ambrosio, U. (2002). Etnomatemática: Elo entre as tradições e a modernidade [Ethnomathematics: Linking tradition with modernity]. Belo Horizonte, MG: Autêntica.

D’Ambrosio, U. (2003). Educação matemática: Da teoria à prática [Etnomathematics: From theory to practice]. Campinas, SP: Papirus.

D’Ambrosio, U. (2004). Posfácio [Afterword]. In J. Ribeiro, M. Domite \& R. Ferreira (Eds.), Etnomatemática: Papel, valor e significado [Ethnomathematics: Role, value and meaning]. São Paulo, SP: Zouk.

D'Ambrosio, U. (2007). Peace, social justice and ethnomathematics. The Montana Mathematics Enthusiast, Monograph 1, 25-34.

D'Angelis, W. (2000). Contra a ditadura da escola: Educação indígena e interculturalidade [Against school dictatorship: Indigenous education and interculturalism]. Cadernos Cedes, $49,18-25$.

Derrida, J. (1976). Of grammatology. Baltimore, MD: The Johns Hopkins University Press.

Dowling, P. (1998). The sociology of mathematics education: Mathematical myths, pedagogic texts. Washington, D.C.: Falmer Press.

Dowling, P. (2001). School mathematics in late modernity: Beyond myths and fragmentation. In B. Atweh, H. Forgasz \& B. Nebres (Eds.), Socio-cultural research on mathematics education: An international perspective. Mahwah: Lawrence Erlbaum.

Duarte, C. (2004). Implicações curriculares a partir de um olhar sobre o "mundo da construção civil" [Curricular implications from a look into the "world of construction"]. In 
G. Knijnik, F. Wanderer, \& C. Oliveira (Eds.), Etnomatemática: Currículo e formação de professores [Ethnomathematics: Curricula and teacher education]. Santa Cruz do Sul, RG: Edunisc.

Evans, J. (1999). Building bridges: Reflections on the problem of transfer of learning mathematics. Educational Studies in Mathematics, 39(1-3), 23-44.

Favilli, F. (Ed.) (2007). Ethnomathematics and mathematics education: Proceedings of the 10th International Congress of Mathematics Education, discussion group 15: Ethnomathematics. Pisa, Italy: Tipografia Editrice Pisana.

Favilli, F. \& Tintori, S. (2007). Intercultural mathematics education: Comments about a didactic proposal. In F. Favilli (Ed.), Ethnomathematics and mathematics education: Proceedings of the 10th International Congress of Mathematics Education, discussion group 15: Ethnomathematics (pp. 39-47). Pisa, Italy: Tipografia Editrice Pisana.

Ferreira, E. (2004). Os índios Waimir-Atroari e a etnomatemática [The Waimir-Atroari and ethnomathematics]. In G. Knijnik, F. Wanderer, \& C. Oliveira (Eds.), Etnomatemática: Currículo e formação de professores [Ethnomathematics: Curricula and teacher education]. Santa Cruz do Sul, RG: Edunisc.

Fiorentino, G. \& Favilli, F. (2007). The eletronic yupana: A didactic resource from an ancient mathematical tool. In F. Favilli (Ed.), Ethnomathematics and mathematics education, Proceedings of the 10th International Congress of Mathematics Education, discussion group 15: Ethnomathematics (pp.49-57). Pisa, Italy: Tipografia Editrice Pisana.

Foucault, M. (2004). Microfisica do poder [Microphysics of power]. Rio de Janeiro, RJ: Edições Graal.

Freire, P. (1998). Cultural action for freedom. Harvard Educational Review, 8(4), 471-521.

Gates, P., \& Zevengergen, R. (2009). Foregrounding social justice in mathematics teacher education. Journal of Mathematics Teacher Education, 12, 161-170.

Gerdes, P. (1995). Ethnomathematics and education in Africa. Stockholm, Sweden: Institute of International Education, University of Stockholm.

Gottschalk, C. (2004). A natureza do conhecimento matemático sob a perspectiva de Wittgenstein: Algumas implicacões educacionais [The nature of mathematical knowledge from the perspective of Wittgenstein: Some educational implications]. Cadernos de História e Filosofia das Ciências, 14(2), 305-334.

Gutiérrez, R. (2007). (Re)Defining equity: The importance of a critical perspective. In N. Nasir \& P. Cobb (Eds.), Improving access to mathematics: Diversity and equity in the classroom. New York and London: Teachers College, Columbia University.

Gutstein, E. (2003). Teaching and learning mathematics for social justice in an urban, latino School. Journal for Research in Mathematics Education, 23(1), 37-73.

Horsthemke, K. \& Schäfer, M. (2006). Does 'African' mathematics facilitate access to mathematics? Towards an ongoing critical analysis of ethnomathematics in a South African context. Paper presented at the Third International Conference on Ethnomathematics: Cultural connections and mathematical manipulations, New Zealand. Subsequently published in Pythagoras, 65, 2-9.

Izquierdo, H. \& Mínguez, A. (2003). Sociological theory of education in the dialectical perspective. In C. Torres \& A. Antikainen (Eds.), The international handbook of the sociology of education: An international assessment of new research and theory. Rowman: Littlefield Publishers.

Jameson, F. (1991). Postmodernism or, the cultural logic of late capitalism. Duke University Press.

Kincheloe, J. \& Steinberg, S. (2008). Indigenous knowledges in education. In N. Denzin, L. Smith and Y. Lincoln (Eds.), Handbook of critical and indigenous methodologies. Thousand Oaks, CA: Sage. 
Knijnik, G. (2004). Etnomatemática e educação no movimento sem terra [Ethnomathematics and education in the landless movement]. In G. Knijnik, F. Wanderer, \& C. Oliveira (Eds.), Etnomatemática: Currículo e formação de professores [Ethnomathematics: Curricula and teacher education]. Santa Cruz do Sul, RG: Edunisc.

Knijnik, G., Wanderer, F., \& Oliveira, C. (Eds.) (2004). Etnomatemática: Currículo e formação de professores [Ethnomathematics: Curricula and teacher education]. Santa Cruz do Sul, RG: Edunisc.

Lacan, J. (2001). Écrits. London, UK: Routledge Classics.

Lave, J. (1988). Cognition in practice: Mind, mathematics and culture in everyday life. Cambridge, NY: Cambridge University Press.

Lave, J. \& Wenger, W. (1991). Situated learning: Legitimate peripheral participation. Cambridge, NY: Cambridge University Press.

Lerman, S. (2000). The social turn in mathematics education research. In J. Boaler (Ed.), Multiple perspectives in mathematics teaching and learning. Westport: Ablex Publishing.

Lizcano Fernández, E. (2004). As matemáticas da tribo europeia: Um estudo de caso [The mathematics of the European tribe: A case study]. In G. Knijnik, F. Wanderer, \& C. Oliveira (Eds.), Etnomatemática: Currículo e formação de professores [Ethnomathematics: Curricula and teacher education]. Santa Cruz do Sul, RG: Edunisc.

Monteiro, A. (2004). A etnomatemática em cenários de escolarização: Alguns elementos de reflexão [Ethnomathematics in schooling scenarios: Some elements for reflection]. In G. Knijnik, F. Wanderer, \& C. Oliveira (Eds.), Etnomatemática: Currículo e formação de professores [Ethnomathematics: Curricula and teacher education]. Santa Cruz do Sul, RG: Edunisc.

National Council of Teachers of Mathematics (2000). Principles and standards for school mathematics. Reston, VA: Author.

Pais, A. (2011). A critical approach to equity in mathematics education. In B. Greer and O. Skovsmose (Eds.), Critique and politics of mathematics education. (in press)

Pais, A., Fernandes, E., Matos, J. F. \& Alves, A. (2011). Methodological issues in critical mathematics education. For the Learning of Mathematics. (in press)

Popkewitz, T. (2004). The alchemy of the mathematics curriculum: Inscriptions and the fabrication of the child. American Educational Research Journal, 41(1), 3-34.

Powell, A. \& Frankenstein, M. (1997). Ethnomathematics: Challenging eurocentrism in mathematics education. Albany, NY: State University of New York Press.

Rowlands, S. \& Carson, R. (2002). Where would formal, academic mathematics stand in a curriculum informed by ethnomathematics? A critical review of ethnomathematics. Educational Studies in Mathematics, 50, 79-102.

Rowlands, S. \& Carson, R. (2004). Our response to Adam, Alangui and Barton's “a comment on Rowlands \& Carson 'Where would formal, academic mathematics stand in a curriculum informed by ethnomathematics?”. Educational Studies in Mathematics, 56, 329-342.

Scandiuzzi, P. (2004). O ensino de matemática na Transamazônica e a velhice Kayabi: Duas experiências de trabalho etnomatemático [The teaching of mathematics in Transamazônica and the Kayabi oldness: two experiences of ethnomathematical work]. In G. Knijnik, F. Wanderer, \& C. Oliveira (Eds.), Etnomatemática: Currículo e formação de professores [Ethnomathematics: Curricula and teacher education]. Santa Cruz do Sul, RG: Edunisc.

Secada, W., Fennema, E. \& Byrd, L. (Eds.) (1995). New directions for equity in mathematics education. Cambridge, NY: Cambridge University Press.

Silver, E. A., \& Herbst, P. (2007). The role of theory in mathematics education scholarship. In F. Lester (Ed.), Second handbook of research in mathematics teaching and learning. New York, NY: Information Age. 
Skovsmose, O. (1994). Towards a philosophy of critical mathematics education. Dordrecht: Kluwer Academic Publishers.

Skovsmose, O. (2005). Travelling through education: Uncertainty, mathematics, responsibility. Rotterdam, The Netherlands: Sense Publishers.

Skovsmose, O., \& Valero, P. (2008). Democratic access to powerful mathematical ideas. In L. D. English (Ed.), Handbook of international research in mathematics education. Mahwah, NJ: Erlbaum. (Second edition)

Skovsmose, O. \& Vithal, R. (1997). The end of innocence: A critique of 'ethnomathematics'. Educational Studies in Mathematics, 34, 131-158.

Stinson, D. (2004). Mathematics as "gate-keeper" (?): Three theoretical perspectives that aim toward empowering all children with a key to the gate. The Mathematics Educator, 14(1), $8-18$.

Valero, P. (2004). Socio-political perspectives on mathematics education. In P. Valero \& R. Zevenbergen, (Eds.), Researching the socio-political dimensions of mathematics education: Issues of power in theory and methodology. Dordrecht, the Netherlands: Kluwer Academic Publishers.

Valero, P. \& Zevenbergen, R. (Eds.). (2004). Researching the socio-political dimensions of mathematics education: Issues of power in theory and methodology. Dordrecht, the Netherlands: Kluwer Academic Publishers.

Vinner, S. (1997). From intuition to inhibition-mathematics education and other endangered species. In E. Pehkonen (Ed.) Proceedings of the 21th Conference of the International Group for Psychology of Mathematics Education (PME21) (Vol. 1, pp.63-78). Lahti, Finland.

Wittgenstein. L. (2002). Investigações filosóficas [Philosophical investigations]. Lisboa, Portugal: Fundação Calouste Gulbenkian. (Third edition)

Žižek, S. (1992). Enjoy your symptom! Jacques Lacan in Hollywood and out. London, UK: Routledge Classics.

Žižek, S. (1997). The plague of fantasies. London, UK: Verso.

Žižek, S. (2004). The ongoing "soft revolution". Critical Inquiry, 30(2) (Online). Retrieved from http://criticalinquiry.uchicago.edu/issues/v30/30n2.Zizek.html, at 14 October 2010.

Žižek, S. (2006). The parallax view. MIT Press.

Žižek, S. (2009). Multiculturalism or the cultural logic of multinational capitalism? Retrieved from $\quad$ http://libcom.org/library/multiculturism-or-the-cultural-logic-of-multinationalcapitalism-zizek, at 4 November 2010. 